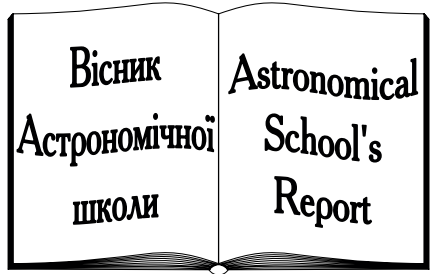

ISSN 2411-6602 (Online)

ISSN 1607-2855 (Print)

Volume $11 \bullet$ Issue $1 \bullet 2015 \quad$ P. $53-55$

UDC 530.12

\title{
Limiting values and general relativity
}

\author{
U.V. Pyrohova ${ }^{1 *}$, O.A. Golubov ${ }^{1,2}$ \\ ${ }^{1}$ Institute of Astronomy of Kharkiv National University \\ ${ }^{2}$ V.N. Karazin Kharkiv National University
}

From the general theory of relativity it is known that the force of gravitational interaction never exceeds the value $F_{\max }=c^{2} / 4 G$. In this paper we try to make the notion of the force limit intuitively understandable, and illustrate it with thought experiments with such exotic objects as black holes. It was found that maximum limits of force, power, and flow of mass exist in nature. These limits are physically equivalent. All the maximum values could be seen only on a black hole surface. Moreover, maximum limits of force, power, and mass flow are inevitable consequences of properties of the event horizon of a black hole. And vice versa, the existence of black holes could be deduced from the principle of the maximum force. So, these three principles also could be considered as features of a black hole. The role played by the maximum force in general relativity is similar to the role played by speed of light in special relativity.

ГРАНИЧНІ ВЕЛИЧИНИ І ЗАГАЛЬНА ТЕОРІЯ ВІДНОСНОСТІ, Пирогова У.В., Голубов О.А. - Із загальної теорї̈ відносності відомо, що сила гравітаційної взаємодї ніколи не перевищує значення максимальної сили $F_{\text {max }}=c^{2} / 4 G$. У изій статті ми намагаємося зробити поняття максимальної сили інтуїтивно зрозумілим, ілюструємо ї̈ в уявних експериментах з такими екзотичними об'єктами, як чорні діри. Було виявлено, що максимальні величини сили, потужності і потоку маси існують у природі. Границі иих величин є фізично еквівалентні. Всі максимальні значення можна побачити тільки на поверхні чорних дір. Крім того, максимальні сили, потужності і масової витрати є неминучими наслідками властивостей горизонту подій чорної діри. I навпаки, наявність чорних дір може бути виведена з принципу максимальної сили. Таким чином, иі три приниципи можна було б також розглядати в якості особливостей чорної діри. Роль максимальної сили у загальній теорії відносності схожа на роль швидкості світла в специіальної теорії відносності.

ПРЕДЕЛЬНЫЕ ВЕЛИЧИНЫ И ОБЩАЯ ТЕОРИЯ ОТНОСИТЕЛЬНОСТИ, Пирогова У.В., Голубов О.А. - Из общей теории относительности известно, ито сила гравитационного взаимодействия никогда не превыщает значения максимальной силь $F_{\max }=c^{2} / 4 G$. В этой статье мы пьтаемся сделать понятие максимальной силь интуитивно понятным, иллюстрируем ее в мысленных экспериментах с такими экзотическими объектами, как черные дыры. Было обнаружено, что максимальные величины силь, мощности и потока массы существуют в природе. Предель этих величин физически эквивалентны. Все максимальные величины можно увидеть только на поверхности черных дыр. Кроме того, максимальные силы, мощности и массового расхода является неизбежным следствием свойств горизонта событий черной дыры. И наоборот, наличие черных дыр может быть выведено из принциипа максимальной силы. Таким образом, эти три принциипа можно было бы также рассматривать в качестве особенностей черной дыры. Роль максимальной силь в общей теории относительности похожа на роль скорости света в специальной теории относительности.

Ключевые слова: общая теория относительности; максимальная сила.

Key words: general relativity; maximum force.

\section{LIMITING VALUES}

\subsection{Limits of force and power}

Similarly to the derivation of special relativity from the notion of speed limit, general relativity can be deduced using the principle of maximum force [1]:

$$
F_{\max } \leqslant \frac{c^{4}}{4 G}=3,0258(4) \cdot 10^{43} \mathrm{~N}
$$

This force limit can be interpreted as the force acting on a body on the surface of a Schwarzschild black hole. If we want to protect the body from falling inside the black hole through its surface, we should pull it back with the maximum possible force and with the maximum possible speed. The energy spent per unit time in this process is the maximum power, which could be ever produced:

$$
P_{\max } \leqslant \frac{c^{5}}{4 G}=9,071(1) \cdot 10^{51} \mathrm{~W} .
$$

The principle of power limit is physically equivalent to the principle of force limit. The former can be deduced from the latter, and vice versa. Mathematically, these two principles differ only by a constant factor,

* Pyrohova Ulyana Vladimirovna; $\$ ulyana487@gmail.com

Astronomical School's Report, 2015, Vol. 11, Issue 1 
namely light speed in vacuum. Therefore, the notion of maximum power could be used as an alternative statement to the notion of maximum force.

$F_{\max }$ and $P_{\max }$ composed only of fundamental constants: the speed of light in vacuum $c$, and the universal gravitational constant $G$. They are obtained from the existence of event horizon (the black hole surface). It is also possible to deduce the existence of black holes from the principle of maximum force or maximum power [2].

The factor $\frac{1}{4}$ is important to get the correct field equation of general relativity from the principles of maximum force (or power). Thus, the maximum force as a limiting value plays the role similar to the role of the maximum speed in special relativity.

\subsection{Limit of mass flow}

The maximum intensity of a black hole evaporation could be attained if the matter goes from the black hole with the light speed. And the minimum time that the evaporation takes is equal to the time, which light requires to pass the distance $R$ from the black hole center to the horizon,

$$
T_{\min }=\frac{R}{c} \text {. }
$$

For a black hole with the mass $M$, and Schwarzschild radius $R=2 M / c^{2}$. So, the maximum intensity of a black hole evaporation is equal to the module of the mass loss per unit time

$$
-\frac{d M}{d t}=\frac{M_{0}}{T_{\min }}=\frac{c^{3}}{4 G},
$$

where $M=M(t)$ is the current mass of black hole, $M_{0}$ is its initial mass.

Thus, we obtain the third limiting value, the maximum possible mass change rate:

$$
\left|\frac{d M}{d t}\right| \leqslant \frac{c^{3}}{4 G} .
$$

As the black hole loses the mass, its momentum can change, but not faster than $\frac{d M c}{d t}$. Corresponding, the change of impulse of the emitted matter is equal to $-\frac{d M c}{d t}$. Thus, the matter that leaves the black hole acts on it with reactive force

$$
-\frac{d M c}{d t}=\frac{c^{4}}{4 G}=F_{\max }
$$

And the maximum power of the black hole evaporation is

$$
-\frac{d M c^{2}}{d t}=\frac{M_{0} c^{2}}{T_{\min }}=\frac{c^{5}}{4 G}=P_{\max } .
$$

This gives a different interpretation to the power limit from Eq.(2).

\section{GEDANKEN EXPERIMENTS}

In order to realize limits of our force and power we consider some thought experiments using simple mechanical reasoning.

\subsection{If there is no power limit for a rocket}

Let us imagine a rocket with reactive engine moving through space-time. If the reactive force acting at the rocket is equal to maximum force, then the exhaust move with the light speed. Correspondingly, when the fuel burns it produces the maximum power. But it could be produced only on the event horizon of a black hole. Thus, a black hole is produced in the nozzle of the rocket.

Therefore, we obtained the following limits for the rocket features:

1) the mass flow could not exceed the value

2) the reactive force could not exceed the $F_{\max }$;

$$
-\frac{d M}{d t} \leqslant \frac{c^{3}}{4 G}
$$

3) the power of burning reactions could not exceed the $P_{\max }$.

And when some process produces the maximum power, a black hole would be made at once.

\subsection{The limit of brute force}

Consider one of the ways for a massive rocket to reside on a black hole event horizon. Let us take the simplest case of black holes: a non-rotating and uncharged black hole, i.e. Schwarzschild black hole.

Assume the mass of the body is much less than the mass of the black hole. In order to counterbalance the gravitational attraction of the black hole, let the rocket circle with the speed of light on the Schwarzschild radius around the back hole center.

Thus, the centrifugal force equals to the force $F_{\text {grav }}$ of gravitational interaction between a black hole with the mass $M$ and a body with the mass $m$. 
In Newtonian mechanics where the speed of light is set infinite, $F_{\text {grav }}=G M m / d^{2}$. Here $d$ is the distance between mass centers of interacting objects. But as the speed of light is finite, the gravitational force obtains the following form,

$$
F_{\text {grav }}=\frac{G M m}{d^{2} \sqrt{1-\frac{2 G M}{d c^{2}}}} .
$$

In our particular problem the mass centers of objects are situated on the distance $d$ equal to the Schwarzschild radius of the black hole. For a black hole with the mass $M$ the Schwarzschild radius is $R=2 M / c^{2}$. But when a massive body appears on the black hole, the mass of the black hole increases by the value of the body's mass, turning into $M+m$. Correspondingly, the black hole radius becomes $R=2 G(M+m) / c^{2}$. So, the larger the mass of the rocket the larger is the radius of the black hole, and the less is the interaction force,

$$
F_{\text {grav }}=\frac{c^{4}}{4 G} \frac{M m}{(M+m)^{2}} \frac{1}{\sqrt{1-\frac{M}{M+m}}} \leqslant \frac{c^{4}}{4 G}=F_{\max } .
$$

In this thought experiment the gravitation force also can not exceed the maximum force.

\subsection{If there is no acceleration limit}

On a black hole surface a rocket could move with the speed of light, and not faster. It follows from the general relativity that even inside the black hole the rocket speed could not be faster than light. But to prove it experimentally one needs to fall through the black hole horizon. So we could not see the rocket acceleration bigger than the one on a black hole surface.

The greater is the velocity of the rocket the larger reactive force must push it, and the more exhausts are needed to be ejected. The matter left behind gravitationaly interacts with the rocket and pulls it back. Usually the rocket velocity is much less then the speed of light, correspondingly the mass of exhausts is insignificant, and its gravitational interaction is negligible. But if the rocket speed tends to the speed of light, the power spent for the acceleration tends to infinity. As products of burning fuel are slower then light, the mass of the exhausts also tends to infinity. And the exhausts would not let the rocket go.

\section{CONCLUSION}

Nowadays the force limit is unattainable in any experiments with real physical substances. But it is possible to understand this limit intuitively.

We considered several particular cases where the maximum force appears as a direct consequence of a black hole nature. We made reasonings about a hypothetical rocket that can move with the light speed.

In one case the rocket was on a supermassive Schwarzschild black hole. It was struggling with the gravitational attraction to escape of falling into the black hole.

In another case the rocket with a reactive engine moved through space-time. Pilots of the rocket tested its ability to move as fast as light. We saw that in motion with the light speed the rocket produced a black hole by itself.

From this reasonings we found that the maximum power and the maximum mass flow also exist in nature. These three maximum values are physically equivalent, and could be derived from each other.

It was shown that when some process produces the maximum power, a black hole is created at once.

Moreover, limits of maximum force, power, and mass flow are an inevitable consequences from the features of an event horizon of a black hole. And vice versa, the existence of black holes could be deduced from the principle of maximum force. So, they also can be considered as features of a black hole.

Acknowledgements. Authors are very grateful to Prof. Yu.L. Bolotin, for introducing them into the topic and for invaluable discussions.

1. Gibbons G.W. (2002). The Maximum Tension Principle in General Relativity // Found. Phys. 32, pp. 1891, arXiv:hep-th/0210109.

2. Schiller C. (2014). Motion Mountain The Adventure of Physics, Relativity, Volume II, 27.06 ed. - P. $103--130$.

3. Barrow J.D., Gibbons G.W. Maximum Tension: with and without a cosmological constant // Mon. Not. Royal Astron. Soc. -2014 . - 446. - P.3874.

Received 18.08.2015

Accepted 10.09.2015 